\title{
Manufacturing of Wear Resistant Iron-Steel: A Theoretical and Experimental Research on Wear Behavior
}

\author{
Oğuzhan Bildik \\ Industrial Design Engineering Department \\ Institute of Graduate Studies \\ Karabuk University \\ Karabük, Turkey \\ oguzhanbildik@gmail.com
}

\author{
Mustafa Yaşar \\ Industrial Design Engineering Department \\ Technology Faculty \\ Karabuk University \\ Karabük, Turkey \\ myasar@karabuk.edu.tr
}

\begin{abstract}
In this study, four different alloys of steel blocks with a thickness of $15 \mathrm{~mm}$ were manufactured in order to develop an alternative to steel plates used in wear exposed areas of construction machines, trucks, and asphalt production plants. To further increase the wear resistance of the manufactured steel blocks, their thickness was reduced to $10 \mathrm{~mm}$ by the hot-rolling method. Wear specimens were obtained from rolled blocks. These specimens were abraded at $20 \mathrm{~N}, 40 \mathrm{~N}$, and $60 \mathrm{~N}$ loads in reciprocating linear motion module ASTM G-33 standards to determine their wear resistance. SEM and EDX analyses were also conducted to see modifications on the worn surfaces. In addition, a theoretical model of wear behaviors was created, calculations were made with Archard wear equation and ANSYS software, and the theoretical and experimental results were compared.
\end{abstract}

Keywords-steel plates; wear; hot rolling; Archard wear analysis

\section{INTRODUCTION}

Steel powerfully impacts the way seven billion of us on the planet go about our daily lives, wherever we are [1]. This effect of steel in our lives brings along some engineering problems. A scientific, engineering and economic problem is the wear of mechanical parts caused by decrease of working surfaces' properties. The wear mechanisms are very complex, due to the interlinked factors. The intensity of interaction depends on the conditions of the environment, in which the mechanical parts are used as well as the type and parameters of the work. Tribological properties such as wear play a critical role in deciding the service life of components that form a moving system or in repetitive/regular contact with each other [2]. Wear resistant plates are a modern solution in the regeneration of worn machine parts and for producing new parts which bring together high wear and abrasion resistance with costs reduction. Authors in [3] examined wear resistant steel materials with different chemical ratios by different manufacturers used in construction machines and similar fields and found that wear behavior and wear amounts in materials vary significantly depending on the chemical content of the material.
In the mineral processing industry, the high stress conditions create a challenging environment for the wear protection steels. Great amounts of highly abrasive rocks are processed and transported in earth construction, excavation, mining, and mineral processing, inducing heavy abrasion, gouging and impact wear. Authors in [4] conducted wear tests at $20 \mathrm{~N}, 40 \mathrm{~N}, 60 \mathrm{~N}$, and $80 \mathrm{~N}$ loads on steel plates with different $\mathrm{C}, \mathrm{Mn}$, and $\mathrm{Si}$ ratios. The $\mathrm{C}$ ratio varied between $0.15 \%$ and $2 \%$ and they found that the wear volume decreased by increasing $\mathrm{C}$ rate [4]. Wear is an important phenomenon that adversely affects the efficiency and lifespan of all machine components in contact under relative motion. In this regard, there is a need to develop new instruments to attain a better understanding of the wear phenomenon. Authors in [5] constructed a tribotester and used the topography of worn surfaces, to provide wear process and wear volume images along with more detailed correlation.

\section{MODEL ANALYSIS}

Prior to casting, Anycasting software was used for casting analysis of the model for molding, filling of the mold and prevention of internal cavities. In the Anycasting, casting shape, casting type, runner, and other parts were first defined with the Anypre module and the mold area was created by selecting the casting area and runner axis [6,7]. Then, a theoretical analysis was carried out as shown in Figure 1 to get results such as casting filling time, solidification time, shrinkage cavities, which are of vital importance. After casting, corrections were made on the model by checking whether shrinkage cavities occurred on the piece. By reverse engineering the resulting model, downsprue, runner, nozzle, vent-riser design and calculations were made for casting [8-10].

\section{MOLD MANUFACTURING}

Most of the pieces manufactured through casting were shaped with the sand casting process. Sand mold casting was conducted by pouring molten metal into a sand mold cavity and after the solidification process, breaking away the sand mold to remove the cast piece [11]. In the model-mold design for sand 
mold casting, the shrinkage allowance on the model and the values obtained from AnyCasting software were checked for relevance. The Model-Flask used in sand mold preparation is shown in Figure 2.

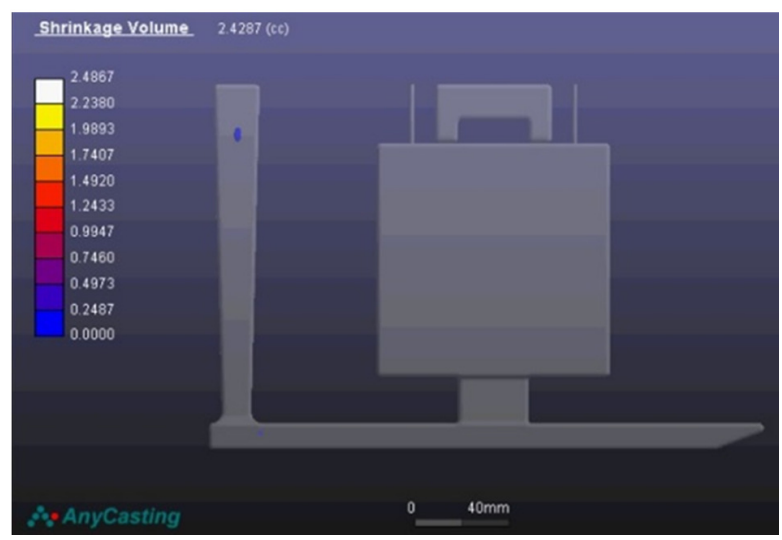

Fig. 1. Shrinkage volume display.

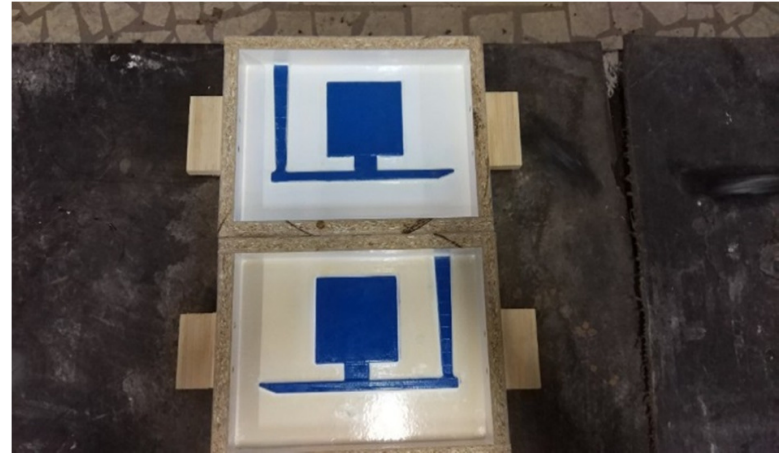

Fig. 2. Flask and model display prior to sand casting.

For the preparation of the flask, $2800 \mathrm{~g}$ of sand, $80-85 \mathrm{~g}$ of resin, and $20-25 \mathrm{~g}$ of chemical hardener were weighed on a precision scale and then were mixed in a separate container manually or by using a machine with adding resin and chemical hardener for 1.5-2 minutes. The mixed sand was emptied on the model inside the flask with a foundry trowel. While emptying the mixture, special attention was paid to the sand squeezing process for proper mold formation. The molds prepared for the casting process were joined together with special adhesive-refractory material. The molds were put in a dryer furnace for dehumidification and made ready for casting before pouring.

\section{POURING PROCESS AND SPECTRAL ANALYSIS}

A single material cannot meet all the high performance needs of long-lasting spare parts, so the properties of the material are improved by alloying through casting [12]. In pouring process, samples were taken from the furnace after burden materials fully melted and reached the desired temperature. The chemical analysis of the samples was carried out in a spectrometer to determine their chemical composition. Proper rates of ferroalloy were added to the first alloys in the furnace after composition values were calculated in the analysis. After reaching the desired rate with calculations and adding ferroalloy, pouring process was completed. The mold was left for cooling and then the pieces were removed from the mold for cooling and cleaning process. The shake out after casting is shown in Figure 3. GNR Atlantis Optical Emission Spectrometer was used for spectral analysis. The rates of cast specimens with different chemical compositions are shown in Table I.

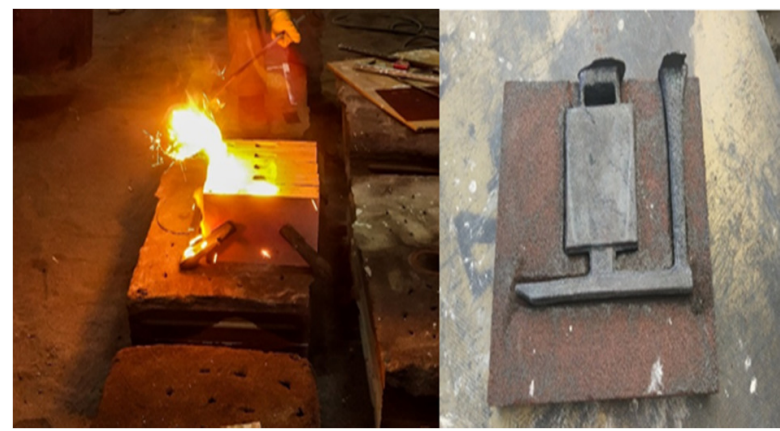

Fig. 3. The pouring moment-mold display after cooling.

TABLE I. CHEMICAL COMPOSITION OF SAMPLES AFTER CASTING

\begin{tabular}{|c|c|c|c|c|}
\hline $\begin{array}{c}\text { Cast specimen } \\
\text { number }\end{array}$ & $\mathbf{1}$ & $\mathbf{2}$ & $\mathbf{3}$ & $\mathbf{4}$ \\
\hline $\begin{array}{c}\text { Specimen } \\
\text { name }\end{array}$ & $\mathbf{N 1}$ & $\mathbf{N 2}$ & $\mathbf{N 3}$ & $\mathbf{N 4}$ \\
\hline $\mathbf{C}$ & 0.48 & 0.54 & 0.59 & 0.58 \\
\hline $\mathbf{M n}$ & $0.95-1.00$ & 1.49 & 1.55 & 1.19 \\
\hline $\mathbf{P}$ & Max-0.016 & Max-0.020 & Max-0.020 & Max-0.019 \\
\hline $\mathbf{S}$ & Max-0.009 & Max-0.011 & Max-0.010 & Max-0.010 \\
\hline $\mathbf{S i}$ & 0.58 & $0.60-0.70$ & 0.49 & $0.60-0.70$ \\
\hline $\mathbf{C r}$ & $1.30-1.40$ & 1.26 & 1.27 & 1.24 \\
\hline $\mathbf{N i}$ & 1.26 & 1.245 & 1.25 & 1.24 \\
\hline $\mathbf{M o}$ & 0.54 & 0.62 & 0.63 & 0.61 \\
\hline
\end{tabular}

\section{ROLLING}

Prior to the rolling process, cast specimens were cut at $100 \times 30 \times 15 \mathrm{~mm}$ dimensions with a cutter in order to match the laboratory draw bench. Then the prepared specimens were heated up to $1200 \pm 10^{\circ} \mathrm{C}$ in a PID controlled furnace with digital temperature and program display for hot rolling process. The $100 \times 30 \times 15$ steel cast specimens were rolled on a draw bench with $150 \mathrm{~mm}$ press surface width and $150 \mathrm{~mm}$ cylinder mill diameter as shown in Figure 4.

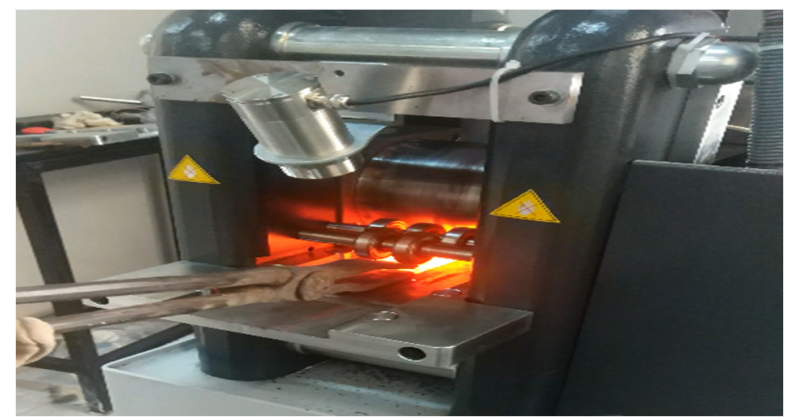

Fig. 4. Rolling process in laboratory conditions. 
The rolling process was done in 3 passes. In the 1 st pass the thickness was reduced to $14 \mathrm{~mm}$, in the 2 nd pass to $12 \mathrm{~mm}$, and in the $3 \mathrm{rd}$ pass to $10 \mathrm{~mm}$. At the end of the rolling process, the average dimensions of the specimens were $140 \times 37 \times 10 \mathrm{~mm}$. The average, measured after rolling, Brinell hardness of the specimens is given in Table II.

TABLE III. AVERAGE BRINELL HARDNESS VALUES AFTER ROLLING

\begin{tabular}{|c|c|}
\hline Specimen name & Brinell hardness(Hv) \\
\hline N1 & 457 \\
\hline N2 & 612 \\
\hline N3 & 605 \\
\hline N4 & 670 \\
\hline
\end{tabular}

\section{WEAR TEST}

Tribometer T10/20 test equipment, manufactured by the UTS company, was used for wear experiments (Figure 5). Before the experiments, the specimens were cut and sandpapered and then mounted on the equipment. The tests were carried out in accordance with reciprocating linear motion module and ASTM G-133 (Standard Test Method for LinearlyReciprocating Ball-on-Flat Sliding Wear) $[11,13] .20 \mathrm{~N}, 40 \mathrm{~N}$, and $60 \mathrm{~N}$ loads were used in tests. Test parameters and load amounts are shown in Table III.

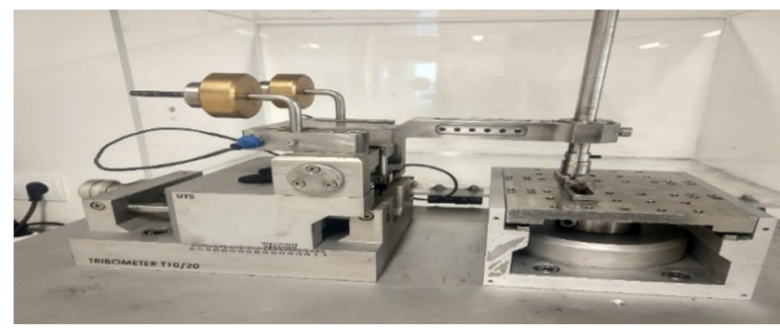

Fig. 5. Test set-up for wear testing.

TABLE II. WEAR TEST PARAMETERS

\begin{tabular}{|c|c|}
\hline Load (F) & $20 \mathrm{~N} / 40 \mathrm{~N} / 60 \mathrm{~N}$ \\
\hline Frequency & $3 \mathrm{~Hz}$ \\
\hline Distance (X) & $7 \mathrm{~mm}$ \\
\hline Sliding distance & $250 \mathrm{~m}$ \\
\hline Sliding velocity & $42 \mathrm{~mm} / \mathrm{s}$ \\
\hline
\end{tabular}

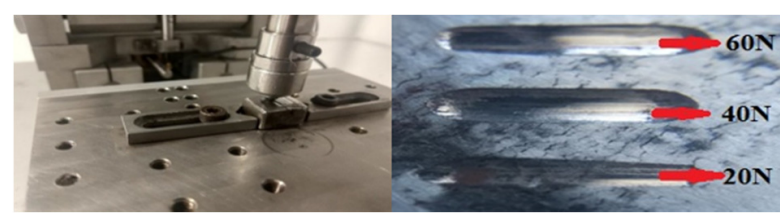

Fig. 6. Images of wear testing and specimen after wear test.

Figure 7(a)-(d) shows the SEM views of the wear surfaces of steel specimens under $60 \mathrm{~N}$ load. It can be seen that there are significant, superficial, groove-like scratches, along with deformation scratches that accumulate on the part that broke after wear and plastic deformation materials dispersed on its surface. It is observed that wear is less in areas with high manganese on their surfaces. Especially in the samples given in Figure 7(b) and (c), it is seen that the amount of abrasion is less and the highest wear occurred in the sample in Figure 7(a). It has been observed that in all the figures, the materials show a serious resistance mechanism against abrasion that can be called abrasion resistant steel [14].
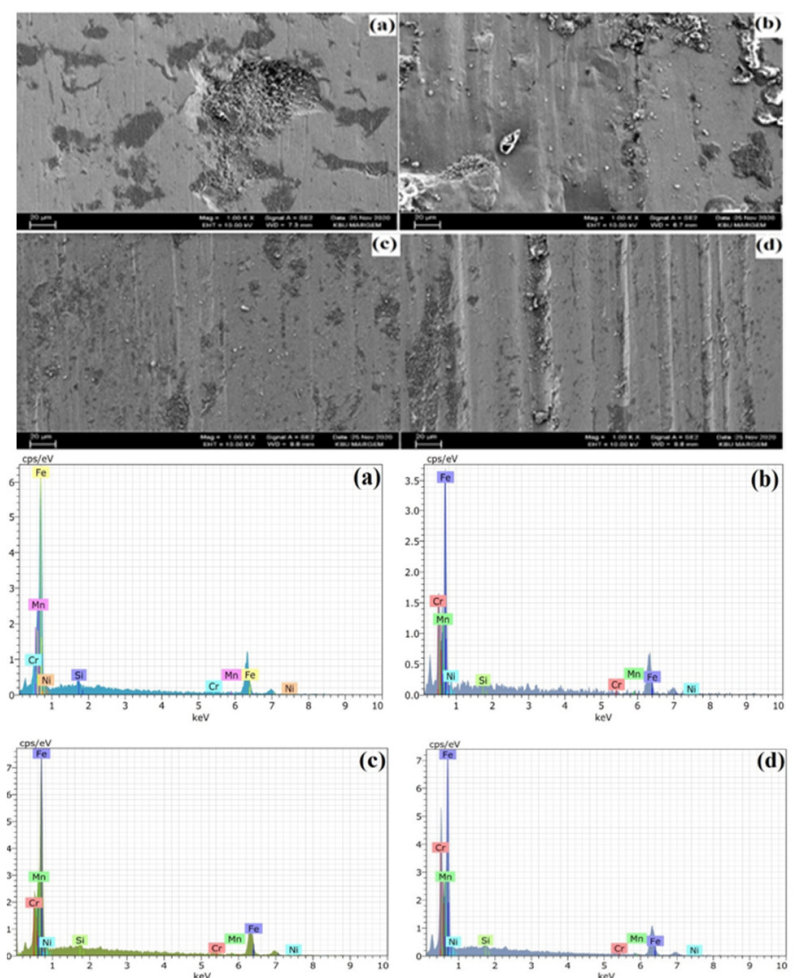

Fig. 7. SEM and EDX images of abrasion test with $60 \mathrm{~N}$ load in $1.00 \mathrm{Kx}$ (a) Sample1, (b) Sample2, (c), Sample3, (d) Sample4.

\section{ARCHARD FEM ANALYSIS AND RESULT COMPARISON}

The Archard wear equation [15-17] or Holm/Archard law, introduced by J.F. Archard in 1953, states the relationship among sliding wear volume $(V)$, normal load $(W)$, total sliding distance $(L)$ and hardness of the softer of two contacting surfaces $(H)$. The classical Archard's wear model is widely used in abrasive wear literature. The Archard's wear equation shows that wear rate is proportional to sliding velocity and normal contact force. The Archard wear model defines wear direction along with wear rate, contact pressure, sliding velocity, and material hardness:

$$
w=\frac{K}{H} P^{m} v^{n}
$$

Values such as wear coefficient, pressure exponent and velocity exponent were taken as constant: $C 1=$ wear coefficient, $K=1.05 \times 10^{-2}, C 2=$ material hardness, $H=$ variable as per specimen hardness [19], $C 3=$ pressure exponent, $m=1$, and $C 4=$ velocity exponent, $n=0$ [20]. Different hardness values were designated as variable for different specimens after casting [18]. Material hardness obtained after rolling were proportioned and hardness values were taken as 2400 for N1, 3250 for N2, 3120 for N3, and 3480 for $\mathrm{N} 4$. 
ANSYS software was utilized for finite element analysis and the experiment set-up shown in Figure 8 was used for each specimen. The wear behavior at $250 \mathrm{~m}$ distance was simulated for $20 \mathrm{~N}, 40 \mathrm{~N}$, and $60 \mathrm{~N}$ loads $[21,22]$.

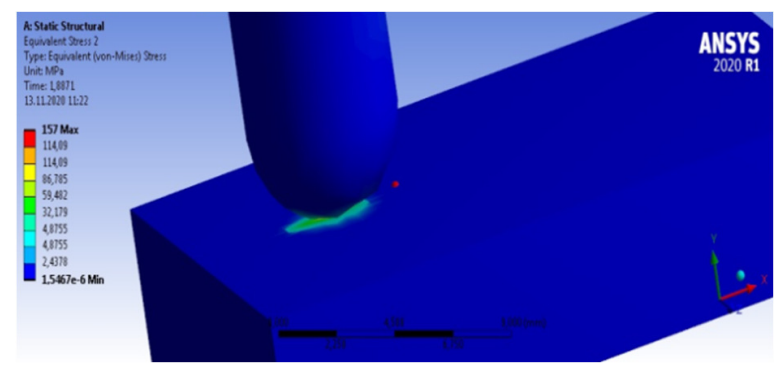

Fig. 8. Finite element analysis and wear image.

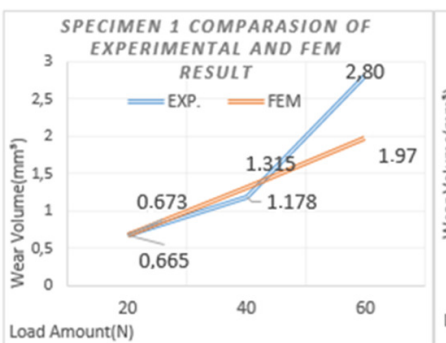

(a)

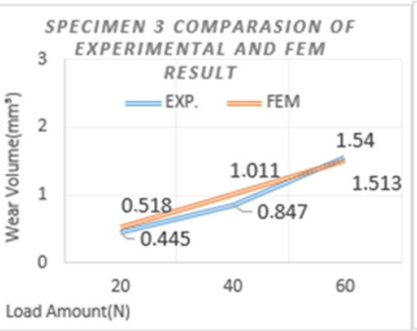

(c)

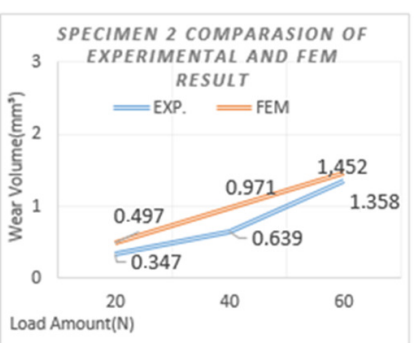

(b)
SPECIMEN 4 COMPARASION OF EXPERIMENTAL AND FEM RESULT

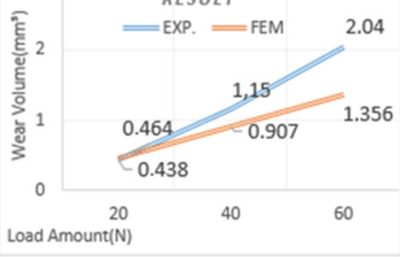

(d)

Fig. 9. Wear test applied to specimens 1,2,3, and 4 in Table I, and wear volume comparison of load amounts as a result of finite element analysis.

The result of wear experiment of Specimen 1 at $20 \mathrm{~N}$ load was $0.665 \mathrm{~mm}^{3}$ and the result from the FEM model was $0.673 \mathrm{~mm}^{3}$ (Figure 9(a)). Both results shown in Figure 9(a) were quite close, suggesting that the simulation and experiment data were consistent with each other. When the load amount reached $40 \mathrm{~N}$, wear volume was observed to increase in accordance with the load both in the experiment and in the finite element analysis. At $60 \mathrm{~N}$ load, the experimental wear volume was $2.80 \mathrm{~mm}^{3}$, while in FEM analysis the wear volume was a bit lower with $1.97 \mathrm{~mm}^{3}$. The result of wear experiment of Specimen 2 at $20 \mathrm{~N}$ load was $0.347 \mathrm{~mm}^{3}$ and the result from the FEM model was $0.497 \mathrm{~mm}^{3}$ (Figure 9(b)). When the load reached $40 \mathrm{~N}$, the wear volume increased in both experimental and finite element analysis to $0.639 \mathrm{~mm}^{3}$ and $0.971 \mathrm{~mm}^{3}$ respectively. At $60 \mathrm{~N}$ load, the experimental wear volume was $1.358 \mathrm{~mm}^{3}$, while in FEM analysis the wear volume was a bit higher with $1.452 \mathrm{~mm}^{3}$. In Figure 9(c) the result of wear experiment of Specimen 3 at $20 \mathrm{~N}$ load was $0.445 \mathrm{~mm}^{3}$ and the result from the FEM model was $0.518 \mathrm{~mm}^{3}$. When the load

reached $40 \mathrm{~N}$, the experimental wear volume of the load was $0.847 \mathrm{~mm}^{3}$ and $1.011 \mathrm{~mm}^{3}$ for FEM. At $60 \mathrm{~N}$ load, the experimental wear volume was $1.54 \mathrm{~mm}^{3}$, while in FEM analysis it was $1.513 \mathrm{~mm}^{3}$. In Figure 9(d), the result of wear experiment of Specimen 4 at $20 \mathrm{~N}$ load was $0.438 \mathrm{~mm}^{3}$ and the result from the FEM model was $0.464 \mathrm{~mm}^{3}$. The results were quite close. When the load amount reached $40 \mathrm{~N}$, the wear volume was observed to increase in both experimental and finite element analysis with $1.15 \mathrm{~mm}^{3}$ and $0.907 \mathrm{~mm}^{3}$ respectively, in accordance with the load. At $60 \mathrm{~N}$ load, the experimental wear volume was $2.04 \mathrm{~mm}^{3}$, while in FEM analysis it was $1.356 \mathrm{~mm}^{3}$.

As can be seen from the results of wear experiment at $20 \mathrm{~N}$ load (Figure 10), the lowest wear volume was at specimen 2 with $0.347 \mathrm{~mm}^{3}$ and the highest wear was $0.665 \mathrm{~mm}^{3}$ at specimen 1 which had the lowest $\mathrm{C}$ amount. Experimental wear and finite element results were very close in all specimens. Wear experiment results and finite element simulation results at $40 \mathrm{~N}$ load are shown in Figure 11. At $40 \mathrm{~N}$ load, the lowest wear value was at specimen 2 with $0.639 \mathrm{~mm}^{3}$ and the highest at specimen 1 with $1.178 \mathrm{~mm}^{3}$. In all wear test results, except specimen 4, experimental wear volume values were lower than the FEM wear values. At $60 \mathrm{~N}$ load, the highest wear was $2.80 \mathrm{~mm}^{3}$ at specimen 1 which had the lowest $\mathrm{C}$ and $\mathrm{Mn}$ content. The wear volume was higher than the FEM value of $1.97 \mathrm{~mm}^{3}$. The lowest wear was at specimen 2 and 3 . These results were very close to the FEM values. The experimental wear volume for specimen 4 was higher than the FEM result.

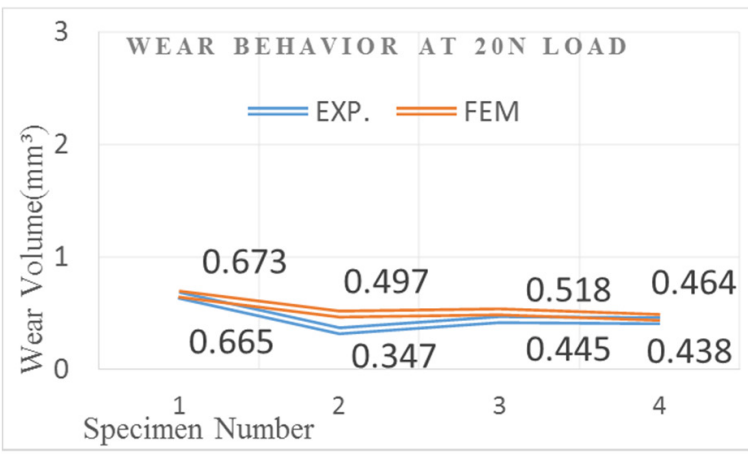

Fig. 10. Wear volume of specimens at $20 \mathrm{~N}$ load wear experiment.

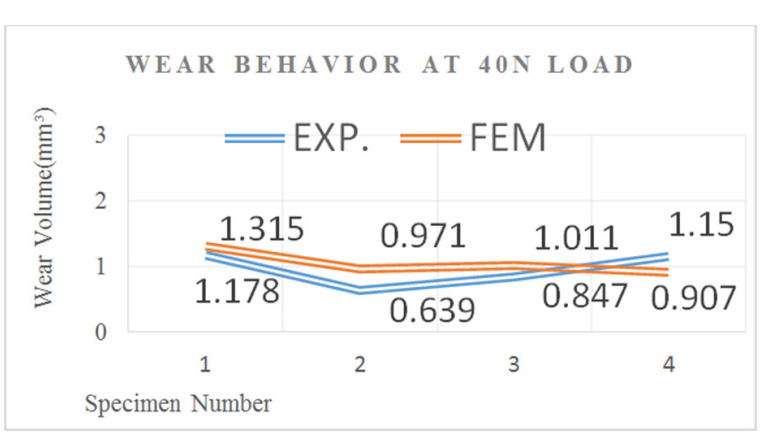

Fig. 11. Wear volume of specimens at $40 \mathrm{~N}$ load wear experiment.

Figure 13 compares the wear values of the manufactured specimens to EN 10029 and EN 10051 standard steel materials, known as wear resistant steel plates in the market. 


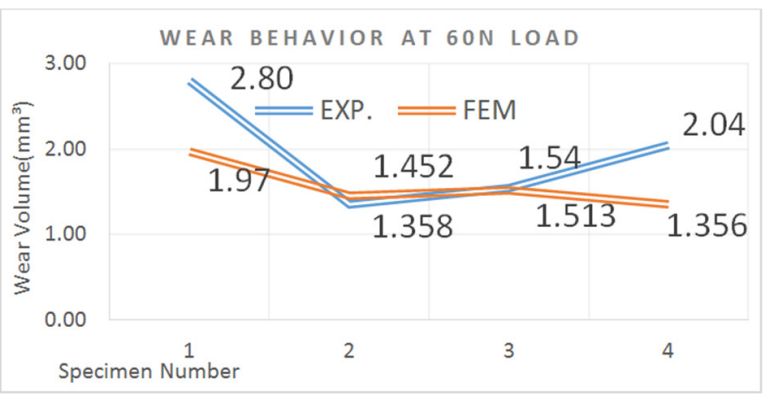

Fig. 12. Wear volume of specimens at $60 \mathrm{~N}$ load wear experiment.

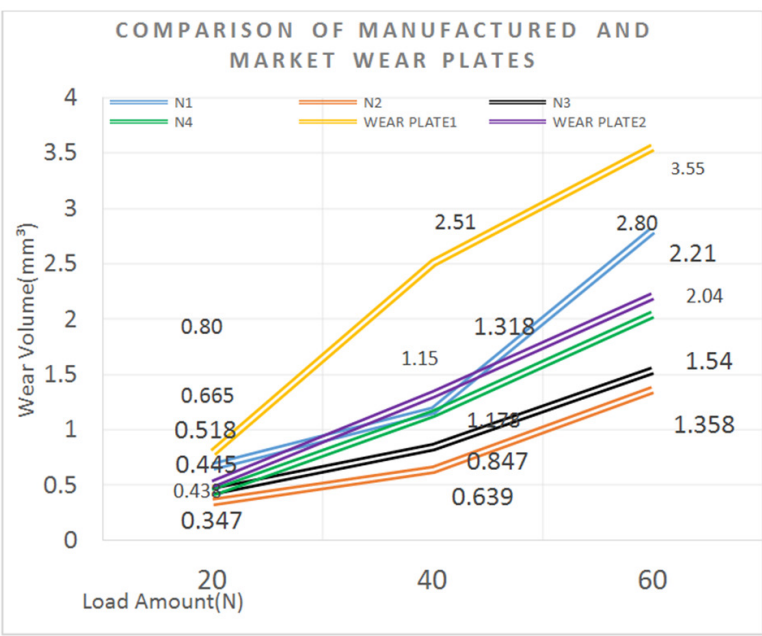

Fig. 13. Comparison of manufactured steel plates and market wear plates.

EN 10051 wear plate number 1 had the lowest wear resistance at all the tests. The EN 10051 wear plate number 2 had higher wear volume than specimens N2, N3, and N4. It had less wear volume than specimen $\mathrm{N} 1$ only at $20 \mathrm{~N}$ and $60 \mathrm{~N}$ tests. At $40 \mathrm{~N}$ test, its wear volume with $1.318 \mathrm{~mm}^{3}$ was higher than specimen N1's.

\section{RESULTS AND EVALUATION}

This study aimed to manufacture different steel which has not yet entered the standards, and to examine its wear behavior. In particular, the aim was to provide an alternative to the wear parts in motorway vehicles which are subject to constant wear and that goal was achieved. Manufacturing conditions were simulated in virtual environment before specimens were cast. The runner and the full filling of the mold cavity with liquid metal were optimized. The mold manufacturing was done in compliance with the conditions and the plates were cast using an induction furnace. As a material standard, different alloy and rolling conditions were tried similar to EN 10029 and EN 10051 standards used in the market. In order to optimize wear conditions, finite element software and Archard wear theory were utilized. The experimental and theoretical results matched by $85 \%$. The compliance rate was low for the results obtained from $60 \mathrm{~N}$ wear load. The reasons are estimated to result from overheating and consequently increase in rupture at wear area. However, the heat effect was not taken into account in the theoretical model.

\section{ACKNOWLEDGMENT}

The work presented in this paper was supported by the University of Karabük Coordinatorship of Research Projects under Project No. KBUBAP-17-DR-271.

\section{REFERENCES}

[1] N. Baluch, Z. M. Udin, and C. S. Abdullah, "Advanced High Strength Steel in Auto Industry: an Overview," Engineering, Technology \& Applied Science Research, vol. 4, no. 4, pp. 686-689, Aug. 2014, https://doi.org/10.48084/etasr.444.

[2] H. Ramadas, S. Sarkar, and A. K. Nath, "Three-body dry abrasive wear properties of $15-5$ precipitation hardening stainless steel produced by laser powder bed fusion process," Wear, vol. 470-471, Apr. 2021, Art. no. 203623, https://doi.org/10.1016/j.wear.2021.203623.

[3] M. Adamiak, G. Jacek, and T. Kik, "Comparison of abrasion resistance of selected constructional materials," Journal of Achievements in Materials and Manufacturing Engineering, vol. 37, no. 2, pp. 375-380, Dec. 2009.

[4] M. Lindroos, K. Valtonen, A. Kemppainen, A. Laukkanen, K. Holmberg, and V.-T. Kuokkala, "Wear behavior and work hardening of high strength steels in high stress abrasion," Wear, vol. 322-323, pp. 32 40, Jan. 2015, https://doi.org/10.1016/j.wear.2014.10.018.

[5] O. V. Penkov, M. Khadem, A. Nieto, T.-H. Kim, and D.-E. Kim, "Design and Construction of a Micro-Tribotester for Precise In-Situ Wear Measurements," Micromachines, vol. 8, no. 4, Mar. 2017, https://doi.org/10.3390/mi8040103.

[6] L. Y. Ni and P. Liu, "Numerical Simulation and Production Trial of Aluminum Alloy Gear Box Housing," Applied Mechanics and Materials, vol. 703, pp. 232-236, 2015, https://doi.org/10.4028/www. scientific.net/AMM.703.232

[7] P.-H. Huang, J.-K. Kuo, T.-H. Fang, and W. Wu, "Numerical simulation and design of casting system for stainless steel exhaust manifold," MATEC Web of Conferences, vol. 185, 2018, Art. no. 00008, https://doi.org/10.1051/matecconf/201818500008.

[8] H.-J. Kwon and H.-K. Kwon, "Computer aided engineering (CAE) simulation for the design optimization of gate system on high pressure die casting (HPDC) process," Robotics and Computer-Integrated Manufacturing, vol. 55, pp. 147-153, Feb. 2019, https://doi.org/ 10.1016/j.rcim.2018.01.003.

[9] Z. Wenshan and L. Shuqin, "Design of drive motor of magnetic levitation artificial heart pump combined with magnetic circuit method and finite element method," Electrical Machinery and Control Applications, vol. 43, no. 4, pp. 71-76, 2016.

[10] B. Dai, H. Gong, D. Kong, and Z. Zhou, "Simulation Analysis and Optimization of Die-Casting for Automobile Steering Valve Shell," Journal of Chongqing University of Technology (Natural Science), vol. $11,2016$.

[11] R. C. Morón et al., "Wear Performance Under Dry and Lubricated Conditions of Post Boriding Heat Treatment in 4140 Steel," Journal of Tribology, vol. 143, no. 2, Aug. 2020, Art. no. 021702, https://doi.org/ 10.1115/1.4047789.

[12] M. Ramadan, "Interface Structure and Elements Diffusion of As-Cast and Annealed Ductile Iron/Stainless Steel Bimetal Castings," Engineering, Technology \& Applied Science Research, vol. 8, no. 2, pp. 2709-2714, Apr. 2018, https://doi.org/10.48084/etasr.1856.

[13] M. I. Pashechko, K. Dziedzic, E. Mendyk, and J. Jozwik, "Chemical and Phase Composition of the Friction Surfaces Fe-Mn-C-B-Si-Ni-Cr Hardfacing Coatings," Journal of Tribology, vol. 140, no. 2, Oct. 2017, Art. no. 021302, https://doi.org/10.1115/1.4037953.

[14] M. P. Groover, Fundamentals of Modern Manufacturing: Materials, Processes, and Systems, 4th ed. Hoboken, NJ, USA: Wiley, 2010.

[15] C. Dong, C. Yuan, X. Bai, J. Li, H. Qin, and X. Yan, "Coupling mechanism between wear and oxidation processes of 304 stainless steel in hydrogen peroxide environments," Scientific Reports, vol. 7, no. 1, May 2017, Art. no. 2327, https://doi.org/10.1038/s41598-017-02530-5. 
[16] J. F. Archard, "Contact and Rubbing of Flat Surfaces," Journal of Applied Physics, vol. 24, no. 8, pp. 981-988, Aug. 1953, https://doi.org/ 10.1063/1.1721448.

[17] T. Dyck and A. Bund, "An adaption of the Archard equation for electrical contacts with thin coatings - PDF Free Download," Tribology International, no. 102, pp. 1-9, 2016.

[18] K. Kato, "Classification of wear mechanisms/models," Proceedings of the Institution of Mechanical Engineers, Part J: Journal of Engineering Tribology, vol. 216, no. 6, pp. 349-355, Jun. 2002, https://doi.org/ $10.1243 / 135065002762355280$.

[19] H. Kloß and M. Woydt, "Prediction of Tribological Limits in Sliding Contacts: Flash Temperature Calculations in Sliding Contacts and Material Behavior," Journal of Tribology, vol. 138, no. 3, May 2016, Art. no. 031403, https://doi.org/10.1115/1.4033132.

[20] A. P. S. Arunachalam and S. Idapalapati, "Material removal analysis for compliant polishing tool using adaptive meshing technique and Archard wear model," Wear, vol. 418-419, pp. 140-150, Jan. 2019, https://doi.org/10.1016/j.wear.2018.11.015.

[21] M. A. Mekicha, M. B. de Rooij, T. Mishra, D. T. A. Matthews, L. Jacobs, and D. J. Schipper, "Study of wear particles formation at single asperity contact: An experimental and numerical approach," Wear, vol. 470-471, Apr. 2021, Art. no. 203644, https://doi.org/10.1016/j.wear. 2021.203644 .

[22] M. A. Ashraf, R. Ahmed, O. Ali, N. H. Faisal, A. M. El-Sherik, and M. F. A. Goosen, "Finite Element Modeling of Sliding Wear in a Composite Alloy Using a Free-Mesh," Journal of Tribology, vol. 137, no. 3, Jul. 2015, Art. no. 031605, https://doi.org/10.1115/1.4029998. 